\title{
FUNGSI ALAT REPIH MASYARAKAT PRASEJARAH TIMUR SABAH
}

\section{(The Function of Flake Tools in Prehistoric Society of East Sabah)}

\author{
Siti Khairani Abd Jalil \\ sitikhairanijalil@gmail.com
}

Pusat Penyelidikan Arkeologi Global, Universiti Sains Malaysia.

Rujukan artikel ini (To cite this article): Siti Khirani Abd Jalil. (2022). Fungsi alat repih masyarakat prasejarah timur Sabah. Melayu: Jurnal Antarabangsa Dunia Melayu, 15(1), 1-24. http://doi.org. 10.37052/jm.15(1)no1

\begin{tabular}{|c|c|c|c|c|c|}
\hline $\begin{array}{l}\text { Peroleh: } \\
\text { Received: }\end{array}$ & $\begin{array}{l}\text { Semakan: } \\
\text { Revised }\end{array}$ & $7 / 4 / 2021$ & $\begin{array}{l}\text { Terima: } \\
\text { Accepted: }\end{array}$ & $27 / 5 / 2021$ & $\begin{array}{l}\text { Terbit dalam talian: } \\
\text { Published online: }\end{array}$ \\
\hline
\end{tabular}

\begin{abstract}
Abstrak
Alat repih merupakan repihan batuan yang digunakan sebagai alat untuk kerja-kerja ringan oleh masyarakat prasejarah. Repihan diperoleh dengan memecahkan batu teras semasa membuat alat pebel. Walau bagaimanapun, repihan yang diperoleh daripada batu teras menunjukkan bahawa terdapat penghasilan khusus untuk dijadikan sebagai alat repih. Penghasilan khusus ini menunjukkan masyarakatnya telah mempunyai pengetahuan menghasilkan alat repih. Alat repih hasil pemukulan manusia dapat dibezakan dengan repihan yang terpecah secara semula jadi berdasarkan ciri-ciri yang terdapat pada bulbar pemukulan, riak dan fisur. Artifak alat repih yang dianalisis adalah dari tapak Paleolitik di Lembah Tingkayu, iaitu tapak terbuka Tingkayu, Gua Madai dan Gua Baturong. Ketiga-tiga tapak ini terletak di bahagian Pantai Timur Sabah. Dua daripadanya merupakan tapak gua daripada formasi batu kapur, iaitu Gua Baturong dan Gua Madai. Sementara tapak Tingkayu ialah tapak terbuka. Analisis alat repih bagi ketiga-tiga tapak ini bertujuan untuk melihat fungsi alat repihnya sama ada mempunyai fungsi yang sama ataupun tidak. Analisis imej perlu dijalankan untuk mengenal pasti fungsi dan ketinggian nilai gilapan yang terhasil bagi aktiviti yang berbeza. Hasil analisis kesan guna menunjukkan masyarakat prasejarah Timur Sabah secara umumnya menggunakan alat repih untuk menggerudi, menghiris, mengikis, meraut dan kegunaan pelbagai fungsi. Kajian ini membuktikan masyarakat awal
\end{abstract}

(C) Dewan Bahasa dan Pustaka. 2022. This work is licensed under the term of the Creative Commons Attribution (CC BY) (http://creative commons.org/licenses/by/4.0/)

ISSN 1675-6460 e-ISSN 2682-8049 
Timur Sabah lebih bersifat ekonomik dalam penghasilan alat batu kerana alat repih digunakan untuk pelbagai fungsi.

Kata kunci: Alat repih, prasejarah, Tingkayu, Madai, Baturong, masyarakat awal Timur Sabah

\begin{abstract}
Flake tools are flakes of stones that were used as a tool for light work by prehistoric society. These flakes are obtained by flaking the core as a process of making a pebble tool. However, the flake that is obtained from the core indicate that there is a specific method to produce the flake tools. This special method shows that the society then already had the knowledge to produce flake tools. Flake tools that come from human striking can be distinguished from naturally cracked fragments based on their characteristics, such as the presence of bulb percussion, ripples and fissures. The artifacts of flake tools that were analysed are from the Paleolithic sites in the Tingkayu Valley, that is, the Tingkayu Open Site, Madai Cave and Baturong Cave. These three sites are located on the East Coast of Sabah. Two of them are cave sites from limestone formations, which are Baturong Cave and Madai Cave, while the Tingkayu site is an open site. The analysis of flake tools in these three sites focuses on the function of flake tools and whether they have the same function or not. Image analysis was conducted to identify the function and value of the flake tools for different activities. The results of the use-wear analysis showed that the prehistoric society of East Sabah in general used flake tools for drilling, slicing, scraping, grinding and other multi-functional purposes. This study proves that the early society of East Sabah were more economical in producing stone tools because they used flake tools for multi-functional purposes..
\end{abstract}

Keywords: Flake tools, prehistoric, Tingkayu, Madai, Baturong, early society of East Sabah

\title{
PENGENALAN
}

Kebanyakan alat repih di Asia Tenggara dikatakan bersifat amorfus disebabkan tiada perapian pada bentuknya. Hal ini menimbulkan tanggapan sesetengah pengkaji terhadap teknologi alat batu di Asia Tenggara sebagai mundur. Malah ada yang percaya bahawa penghasilan alat repih ini adalah untuk menghasilkan alat sekunder seperti buluh, kayu dan sebagainya (Pope, 1989; Dibble \& Pelcin, 1995; Mokhtar \& Jeffrey, 2007; Otte, 2010; Bar-Yosef \& Wang, 2012; Hazarika, 2012; Gao, 2013). Namun begitu, alat repih tapak terbuka Tingkayu sahaja yang mempunyai bentuk yang jelas (Mokhtar, 
2014). Malah alat repihnya didapati telah mengalami perapian bentuk secara bifas dan unifas. Keadaan ini menunjukkan bahawa penghasilan alat repih di tapak Tingkayu telah mengalami beberapa peringkat perepihan sehingga terhasilnya perapian pada bentuknya. Kajian oleh Mokhtar (1998) telah membuktikan bahawa tapak Tingkayu turut menghasilkan pelbagai alat repih terutamanya alat repih jenis burin.

Menurut Bellwood (1988), tapak terbuka Tingkayu merupakan bengkel pembuatan alat batu bifas. Sementara itu, tapak Baturong dan Madai pula dikatakan sebagai berteknologikan alat repih dan alat pebel yang berbeza dengan tapak terbuka Tingkayu. Pentarikhan mutlak dilakukan dengan kaedah Radiokarbon yang menunjukkan bahawa Baturong berusia sekitar 18,000 tahun, sementara Madai pula berusia 11,000 tahun. Sementara tapak terbuka Tingkayu menggunakan kaedah pentarikhan pendar kilau rangsangan optik (OSL). Hasil pentarikhan tersebut telah mendapati bahawa usia tapak terbuka Tingkayu adalah sekitar 12000 tahun dahulu, iaitu hampir sama dengan tapak Madai (Mokhtar, 1998). Pentarikhan Tapak Tingkayu dan Madai adalah hampir sezaman, manakala tapak Baturong pula lebih tua. Berdasarkan perbezaan usia tapak, mungkin terdapat perbezaan dari segi fungsi alat repih ketiga-tiga tapak ini. Selain itu, sumber material untuk menghasilkan alat repih juga berbeza. Material tapak Tingkayu diperoleh secara kuari daripada Formasi Kuamut (Jaffrie, 2000). Alat repih daripada tapak Baturong dan Madai pula dihasilkan menggunakan material daripada Formasi Chert Spilite, iaitu daripada pebel sungai (Bellwood, 1988). Material rijang dari Formasi Kuamut dikatakan lebih baik berbanding dengan batuan rijang Formasi Chert Spilite. Oleh sebab itu, Bellwood telah mengaitkan kehalusan alat yang dihasilkan di tapak terbuka Tingkayu dengan mutu material rijang yang digunakan. Oleh sebab alat repih tapak Tingkayu dihasilkan dengan lebih kemas dengan menggunakan material yang baik, maka persoalan tentang sama ada wujud penghasilan alat repih yang khusus kepada fungsi tertentu belum lagi terjawab.

Kajian kesan guna oleh Bellwood (1988) dengan menggunakan kaedah pembesaran kuasa rendah (10-20x) menunjukkan bahawa alat repih tapak Tingkayu berfungsi untuk menggergaji, mengikis dan meraut, manakala, tapak Madai dan Baturong masih belum ada kajian kesan guna dijalankan terhadap alat repihnya. Oleh itu, sukar untuk mentafsirkan fungsi alat repih Lembah Tingkayu secara keseluruhannya. Kemungkinan, ketiga-tiga tapak ini menghasilkan fungsi alat repih yang berbeza-beza ataupun mempunyai fungsi yang lebih spesifik mengikut teknologi alat repihnya. Pengkaji Barat menyatakan bahawa alat repih di Asia Tenggara hanya digunakan untuk menghasilkan alat-alat daripada kayu dan buluh sahaja (Narr, 1966; Solheim 1970; Mijares 2002; Mellars 2006; Dennell, 2009). Oleh itu, Movius telah meletakkan Garis Movius yang membahagikan antara kawasan Barat dan Timur (Asia) telah dikaitkan dengan penggunaan buluh sebagai alat di kawasan Asia termasuk Asia 
Tenggara (Otte, 2010). Kawasan sebelah timur ini dikatakan mempunyai banyak tumbuhan seperti buluh (Elton, 2008). Para pengkaji cuba mengaitkan teknologi litik dengan persekitarannya. Walau bagaimanapun, idea tentang penggunaan alat sekunder seperti alat buluh ini masih lagi tidak jelas dan tiada bukti yang kukuh (Pawlik, 2004). Keadaan ini berlaku kerana alat daripada bahan organik ini tidak bertahan lama, maka bukti ini sukar diperoleh kecuali melakukan analisis kesan guna atau analisis sisa pada alat repih tersebut. Oleh itu, analisis kesan guna perlu dijalankan untuk menjawab persoalan tentang fungsi alat repih di Lembah Tingkayu dan menambah data fungsi bagi alat repih di Asia Tenggara.

\section{ANALISIS IMEJ DALAM MENENTUKAN FUNGSI ALAT REPIH}

Analisis secara makro dan mikro telah dijalankan terhadap 32 alat repih Lembah Tingkayu, iaitu 10 alat repih daripada tapak Madai (Rajah 1), 11 alat repih daripada tapak Tingkayu (Rajah 2), dan 11 alat repih daripada tapak Baturong (Rajah 3). Alat repih ini dipilih berdasarkan atribut kesan guna yang paling ketara pada mata tepi yang boleh diperhatikan secara makro (mata kasar). Kesemua 32 alat repih ini adalah alat repih jenis bergerigi yang terdiri daripada pelbagai mata tepi, iaitu tirus, lurus, cembung dan cekung. Teknik analisis imej telah digunakan untuk mengenal pasti fungsi alat repih Lembah Tingkayu ini. Analisis imej merupakan satu kaedah
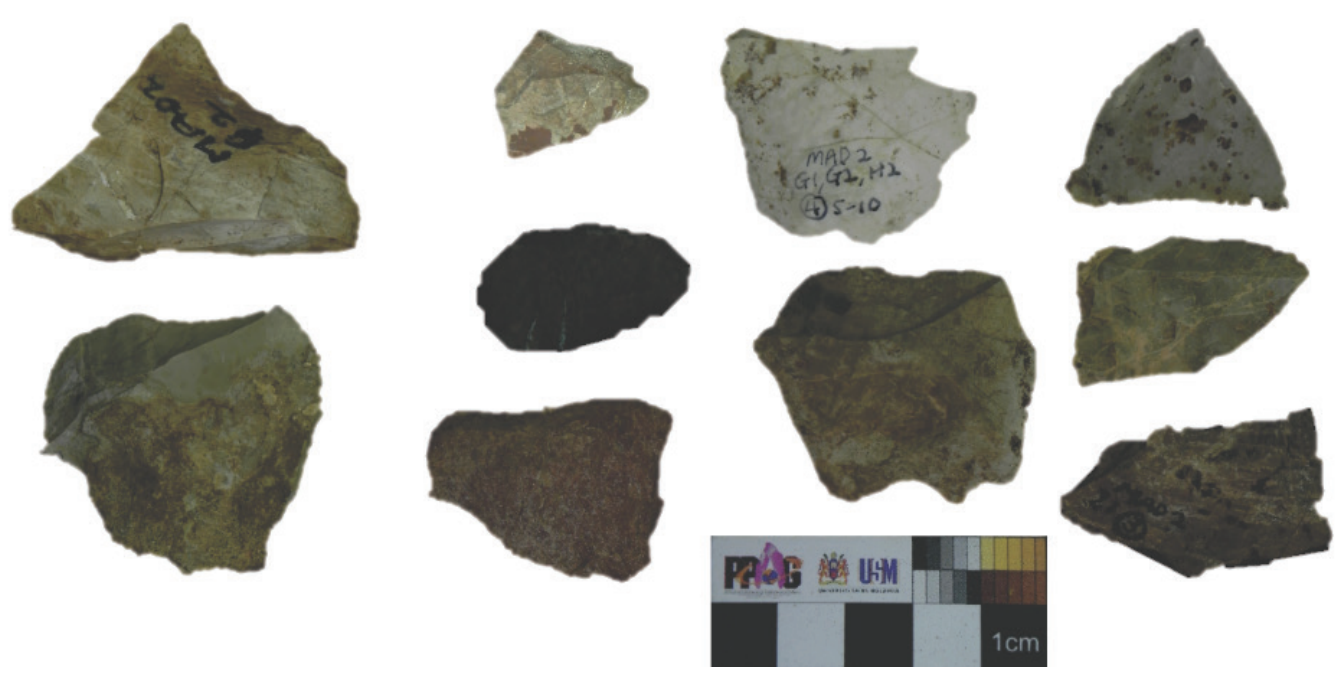

Rajah 1 Alat repih bergerigi dari tapak Madai yang terdiri daripada pelbagai jenis mata. 


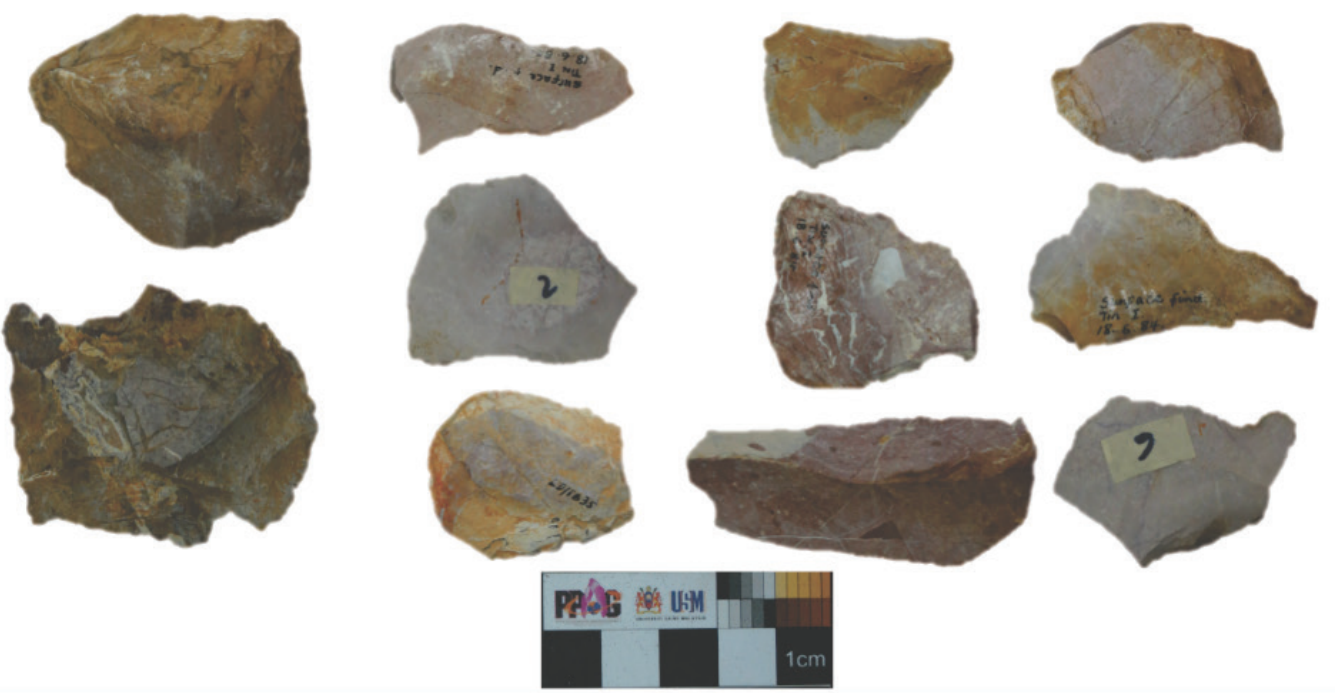

Rajah 2 Alat repih bergerigi dari tapak Tingkayu yang terdiri daripada pelbagai jenis mata.
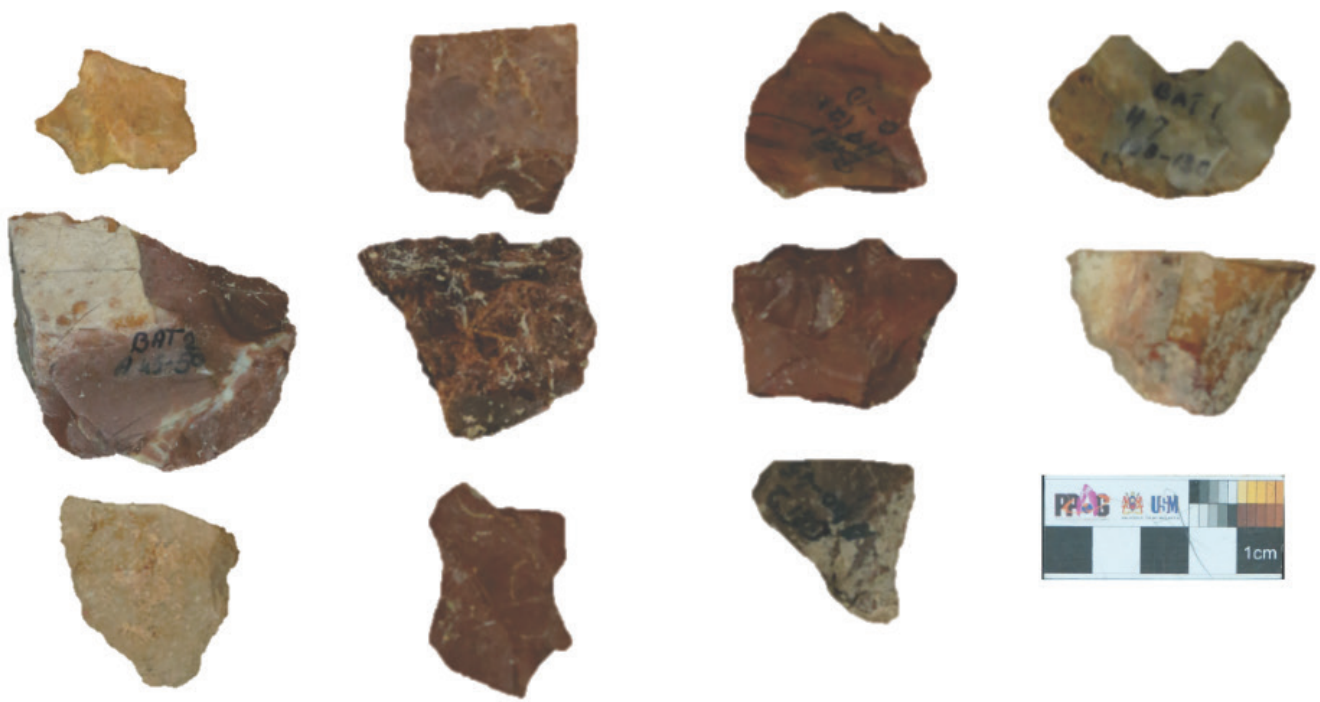

Rajah 3 Alat repih bergerigi dari tapak Baturong yang terdiri daripada pelbagai jenis mata. 
daripada aplikasi digital untuk mengenal pasti nilai warna yang terasing daripada warna asal objek (González Urquijo \& Ibáñez Estévez, 2003; Barceló Álvarez et al., 2008). Kaedah ini sering digunakan sebagai alat diagnostik yang telah digunakan dalam pelbagai bidang penyelidikan, termasuk perubatan, kejuruteraan dan sains gunaan (Cootes, 2000; Graham, 2000; Parr \& Polzleitner, 2001; Rottensteiner, 2001; Yoo \& Metaxas, 2005; Moreaud et al., 2009; Xu et al., 2011; Gramfort et al., 2014).

Analisis imej merupakan satu daripada pendekatan untuk menentukan fungsi alat batu dengan menggunakan imej daripada analisis mikro. Analisis ini hanya menggunakan atribut kesan gilapan pada mata tepi yang memberikan perubahan ketara pada profil nilai kelabu yang menunjukkan fungsi tertentu pada alat batu (Lerner, 2007a, 2007b). Analisis ini juga digunakan untuk membezakan alat repih dengan puingan, iaitu imej secara mikro ditafsirkan mengikut ketinggian bentuk permukaan melalui plot profil kelabu yang dihasilkan. Imej dikecilkan kepada imej persegi menggunakan tiga paksi utama sebagai jarak sempadan. Nilai ketinggian permukaan kelabu bergantung pada jarak piksel imej tersebut (Lerner et al., 2009). Maka, kesan haus pada permukaan alat repih dapat dikenal pasti melalui tinggi rendah permukaan alat repih melalui bacaan profil nilai kelabu. Menurut Stemp dan Stemp (2001) kekasaran permukaan akan mempengaruhi data plot nilai kelabu yang terhasil pada permukaan. Repihan yang tidak digunakan akan menghasilkan permukaan mata tepi yang kasar dan tidak akan menghasilkan variasi plot permukaan yang berbeza pada profil nilai kelabu. Alat repih pula akan menghasilkan permukaan yang licin pada bahagian mata tepi yang telah digunakan dan permukaan yang kasar pada bahagian yang tidak digunakan. Oleh itu, terbentuk variasi yang berbeza pada profil nilai kelabu. Analisis profil nilai kelabu merupakan analisis yang melibatkan data secara kuantitatif pada sesuatu permukaan. Metod ini sesuai digunakan untuk mengenal pasti fungsi alat repih secara kuantitatif berdasarkan jarak piksel imej.

Fungsi alat repih dapat dibahagikan kepada gerakan mendatar, menegak dan putaran. Gerakan mendatar terdiri daripada aktiviti menggergaji, menggores dan menghiris sementara gerakan menegak pula mewakili aktiviti meraut. Selain itu, gerakan putaran pula terdiri daripada aktiviti menggerudi. Kesemua gerakan ini dapat dibezakan melalui perbezaan nilai kelabu yang dikesan melalui perkembangan gilapan pada mata tepi alat. Jelas atau tidak atribut kesan gilapan yang terhasil ini bergantung pada jenis media dan masa yang digunakan serta jenis batuan alat repih. Oleh itu, jika media jenis lembut atau digunakan dalam masa yang singkat, profil nilai kelabu yang dihasilkan adalah tidak jelas. Malah batuan yang berlainan juga akan memberikan nilai kelabu yang berbeza.

Oleh itu, analisis imej secara tidak langsung membantu untuk menentukan ukuran perkembangan dan bentuk gilapan pada permukaan batuan dengan lebih terperinci. 
Kaedah ini membuktikan bahawa alat repih bukan sahaja boleh diukur tetapi juga boleh ditentukan nilai perkembangan gilapan berdasarkan jumlah bilangan piksel sesuatu imej. Kaedah ini mengenal pasti sekurang-kurangnya sebahagian daripada sifat tertentu permukaan setiap bahan (Lerner, 2007a, 2007b, 2009; Lerner et al., 2010). Kaedah ini telah digunakan dalam beberapa kajian kesan gunaan terhadap batuan dan media yang berbeza (Lerner, 2007a, 2007b, 2009). Analisis imej yang digunakan oleh Lerner (2007a, 2007b) ini adalah untuk mengesan taburan gilapan berdasarkan nilai kelabu yang tinggi (threshold). Maka, melalui analisis ini, pemerhatian terhadap perbezaan taburan gilapan antara dua jenis batuan ini akan lebih jelas dan mudah (Lerner, 2007a, 2007b, 2009, 2010). Selain itu, perbezaan kecerunan perkembangan gilapan pada mata tepi dapat dikenal pasti melalui (Lerner et al., 2010).

\section{Gerakan Melintang}

Berdasarkan hasil analisis secara mikro melalui mikroskop stereo taburan gilapan terdiri daripada dua ciri utama, iaitu bersela dan berterusan. Taburan gilapan yang bersifat berterusan yang terhasil pada mata tepi repihan batuan rijang adalah disebabkan

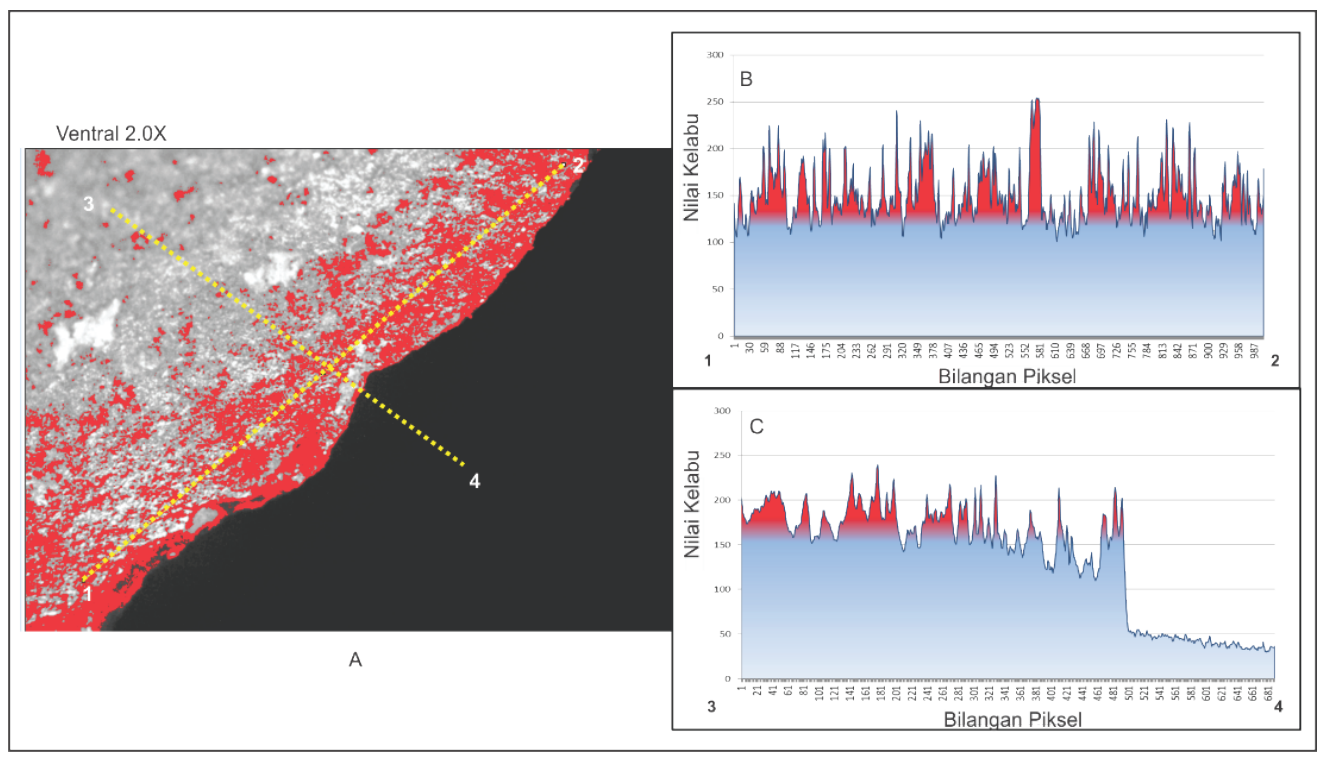

Rajah 4 (A) Analisis imej taburan kesan gilapan pada alat repih Baturong dengan petunjuk berwarna merah yang mempunyai nilai kelabu yang tinggi bagi gerakan melintang. (B) Profil gilapan yang selari dengan mata tepi. (C) Profil gilapan menegak dengan mata tepi. 
oleh tekstur permukaan repihan batuan rijang yang rata dan halus. Tekstur permukaan yang rata memudahkan penyebaran taburan gilapan dan menghasilkan taburan yang bersifat sekata dan berterusan (Grace et al., 1985; Sussman, 1985).

Rajah 4, Rajah 5 dan Rajah 6 menunjukkan bacaan nilai kelabu batuan rijang hasil daripada analisis imej yang telah dijalankan terhadap mata tepi alat repih tapak Baturong, Madai dan Tingkayu. Kawasan gilapan merupakan kawasan yang mempunyai nilai kelabu yang tinggi dalam analisis imej yang ditunjukkan oleh kawasan yang berwarna merah (Ibáñez et al., 2014, Lerner et al., 2010; Stemp \& Stemp, 2001). Taburan berwarna merah ini mempunyai nilai kelabu yang tinggi pada profil rentasan. Berdasarkan corak profil tersebut didapati kawasan gilapannya adalah berterusan pada kedua-dua profil rentasan tersebut. Hal ini menunjukkan bahawa taburan gilapannya adalah menyeluruh bagi alat repih tapak Baturong, Madai dan Tingkayu.

Alat repih dari tapak Baturong, Madai dan Tingkayu menghasilkan atribut gilapan dan glos secara selari dengan mata tepi. Gilapan selari dengan mata tepi ini akan menghasilkan nilai kelabu dengan kawasan yang berwarna merah selari dengan mata tepi. Taburan berwarna merah ini bergantung pada jenis material. Material alat repih daripada tapak Baturong dan Madai (Rajah 4 dan Rajah 5) menghasilkan taburan berwarna merah yang tidak sekata dan bersela berbanding taburan berwarna merah yang terhasil pada mata tepi alat repih Tingkayu (Rajah 6). Hal ini terjadi kerana alat repih daripada tapak Tingkayu menggunakan batuan rijang daripada Formasi Kuamut yang lebih halus berbanding dengan material rijang Formasi Chert Spilite tapak Baturong dan Madai.

Namun begitu, alat repih daripada tapak Baturong dan Madai masih menghasilkan nilai kelabu yang tinggi. Keadaan ini sedemikian kerana taburan berwarna merah yang terhasil adalah jelas menunjukkan gerakan melintang telah dijalankan terhadap alat repih. Sementara alat repih Tingkayu pula, menunjukkan taburan berwarna merah yang lebih sekata dan berterusan memandangkan permukaan mata tepi alat repihnya lebih halus (Rajah 6). Ketiga-tiga alat repih dari tapak Lembah Tingkayu ini menghasilkan taburan berwarna merah yang selari dengan mata tepi. Keadaan ini menunjukkan alat repih telah digunakan untuk tujuan menggergaji atau menghiris. Perbezaan analisis imej bagi aktiviti menggergaji dengan menghiris ialah bacaan taburan berwarna merah bagi aktiviti menghiris adalah tidak berterusan dan lebih memanjang ke dalam pada mata tepi alat repih. Taburan berwarna merah bagi aktiviti menghiris lebih pendek dan setempat berbanding dengan taburan berwarna merah yang terhasil daripada aktiviti menggergaji. Sementara aktiviti menggergaji pula menghasilkan taburan berwarna merah di sepanjang mata tepi dan tidak ke dalam. Alat repih dari tapak Baturong dan Tingkayu digunakan untuk menggergaji (Rajah 4 dan Rajah 6), manakala alat repih daripada tapak Madai pula berfungsi untuk menghiris (Rajah 5). 


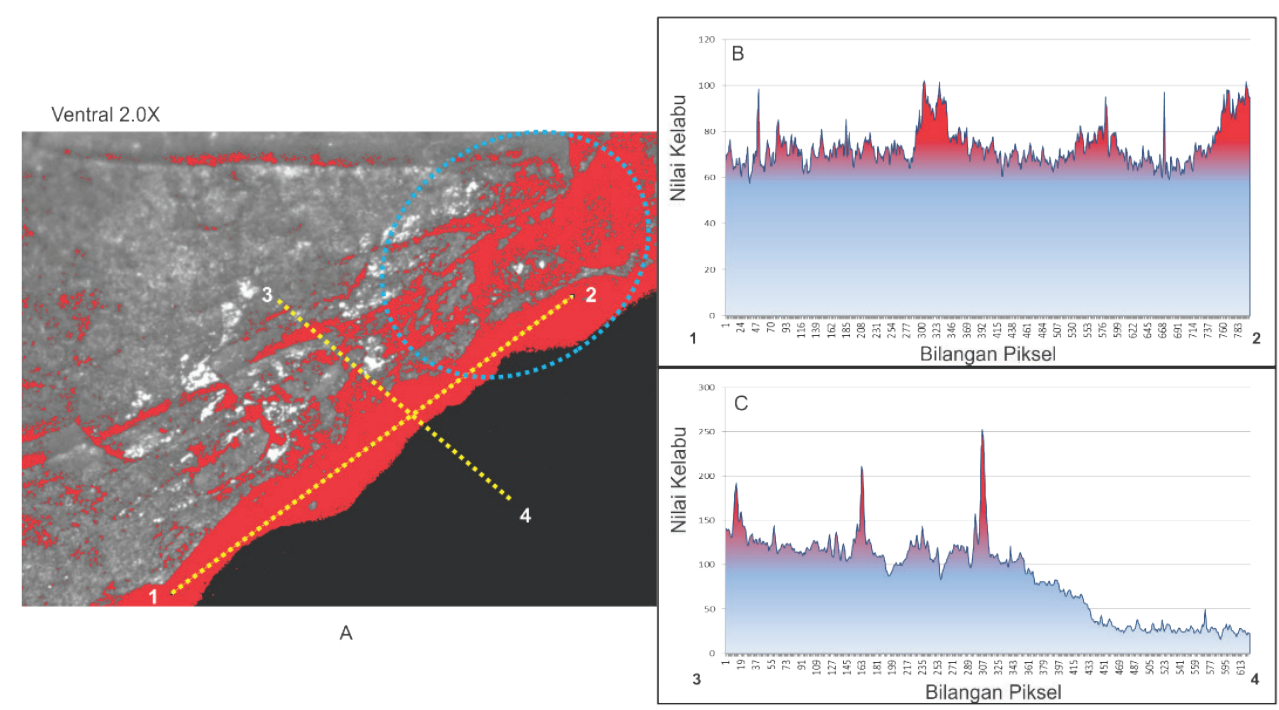

Rajah 5 (A) Analisis imej taburan kesan gilapan pada alat repih Madai dengan petunjuk berwarna merah yang mempunyai nilai kelabu yang tinggi bagi gerakan melintang. (B) Profil gilapan yang selari dengan mata tepi. C) Profil gilapan menegak dengan mata tepi.

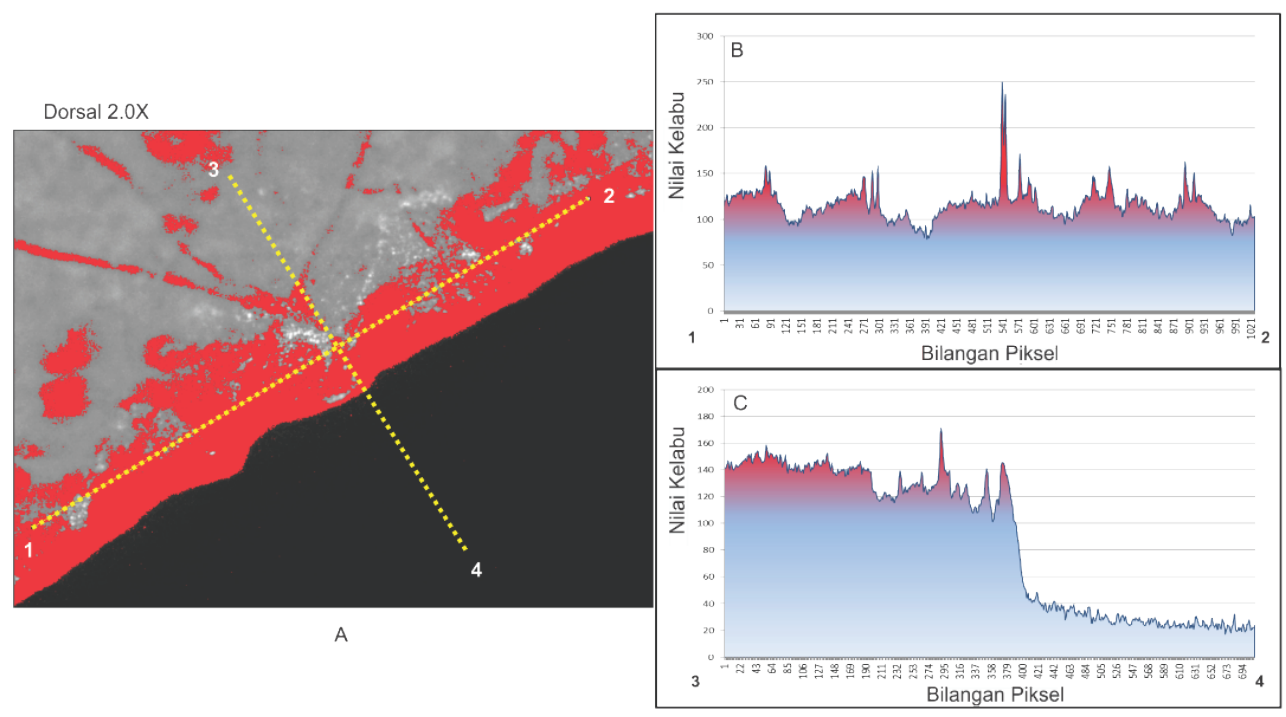

Rajah 6 A) Analisis imej taburan kesan gilapan pada alat repih Tingkayu dengan petunjuk berwarna merah yang mempunyai nilai kelabu yang tinggi bagi gerakan melintang. (B) Profil gilapan yang selari dengan mata tepi. (C) Profil gilapan menegak 
Perkembangan gilapan yang tinggi pada ketiga-tiga alat repih batuan rijang telah menghasilkan nilai kelabu yang berbeza-beza pada mata tepi repihan berdasarkan petunjuk berwarna merah (Lerner et al., 2010). Nilai kelabu ini bergantung pada tekstur permukaan mata tepi alat repih. Alat repih dengan tekstur yang lebih halus akan menghasilkan petunjuk berwarna merah yang lebih menyeluruh. Sebaliknya, jika permukaan tekstur mata tepi alat repih tidak licin maka petunjuk berwarna merah akan bersela. Oleh itu, ketiga-tiga alat repih ini menghasilkan petunjuk berwarna merah yang bersela dan menyeluruh di sepanjang mata tepi alat repih. Hal ini menunjukkan bahawa ketiga-tiga mata tepi alat repih daripada Lembah Tingkayu ini menghasilkan gilapan dan glos.

\section{Gerakan Menegak}

Hasil analisis imej terhadap alat repih tapak Baturong, Madai dan Tingkayu menunjukkan taburan merah secara menegak. Gerakan menegak telah menghasilkan taburan merah secara vertikal yang menjauh ke dalam mata tepi alat repih. Gerakan menegak ini terhasil daripada aktiviti mengikis atau meraut. Gerakan menegak terhadap mata tepi alat repih menyebabkan ketiga-tiga alat repih tapak Baturong, Madai dan Tingkayu menghasilkan corak nilai kelabu yang sama tetapi taburannya berbeza-beza. Taburan merah pada alat repih Baturong dan Madai lebih bersifat bersela (Rajah 7 dan Rajah 8) berbanding taburan merah pada alat repih tapak Tingkayu yang lebih bersifat sekata dan berterusan (Rajah 9). Berlakunya keadaan sedemikian berkemungkinan disebabkan oleh jenis aktiviti dan permukaan tekstur batuan yang berbeza-beza.

Melalui analisis imej, aktiviti meraut dan mengikis dapat dibezakan melalui taburan merah kerana nilai kelabu yang dihasilkan bagi kedua-dua aktiviti ini adalah berbeza. Nilai kelabu bagi aktiviti mengikis lebih tinggi dan menumpu kepada sudut mata tepi alat repih. Maka taburan yang terhasil pada mata alat repih lebih banyak pada bahagian sudut dan bersifat setempat. Untuk nilai kelabu bagi aktiviti meraut pula lebih menegak ke dalam (pada permukaan mata tepi) dan bersifat setempat. Nilai kelabu ini dipengaruhi oleh cara alat repih dipegang oleh si pengguna. Memandangkan pergerakan aktiviti mengikis lebih menumpu pada bahagian sudut maka atribut gilapan dan glos lebih banyak terhasil pada bahagian sudut mata tepi alat repih. Sementara, aktiviti meraut pula pergerakannya adalah lebih condong dengan media kerja. Oleh itu, atribut gilapan dan glos lebih banyak terhasil pada permukaan mata tepi aktiviti meraut. Oleh yang demikian, hasil analisis imej ini menunjukkan bahawa alat repih dari tapak Baturong berfungsi untuk mengikis (Rajah 7), manakala alat repih dari tapak Madai dan Tingkayu pula berfungsi untuk meraut (Rajah 8 dan Rajah 9). 


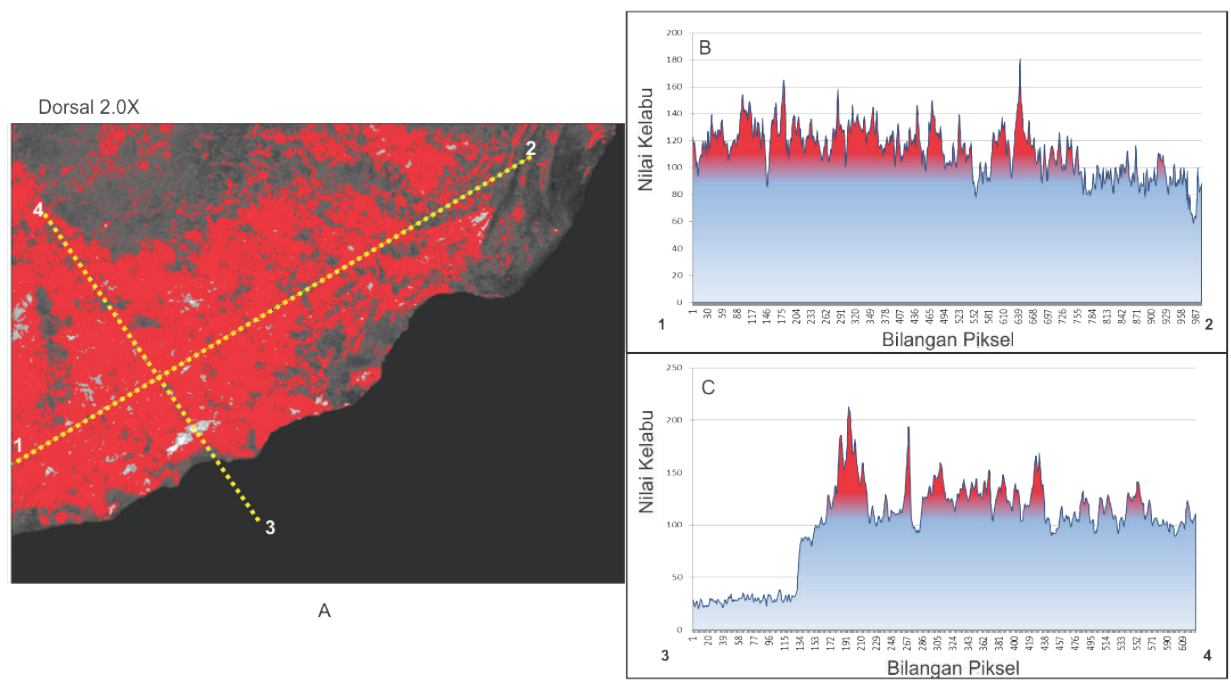

Rajah 7 (A) Analisis imej taburan kesan gilapan pada alat repih Baturong dengan petunjuk berwarna merah yang mempunyai nilai kelabu yang tinggi bagi gerakan menegak. (B) Profil gilapan yang selari dengan mata tepi. (C) Profil gilapan menegak dengan mata tepi.

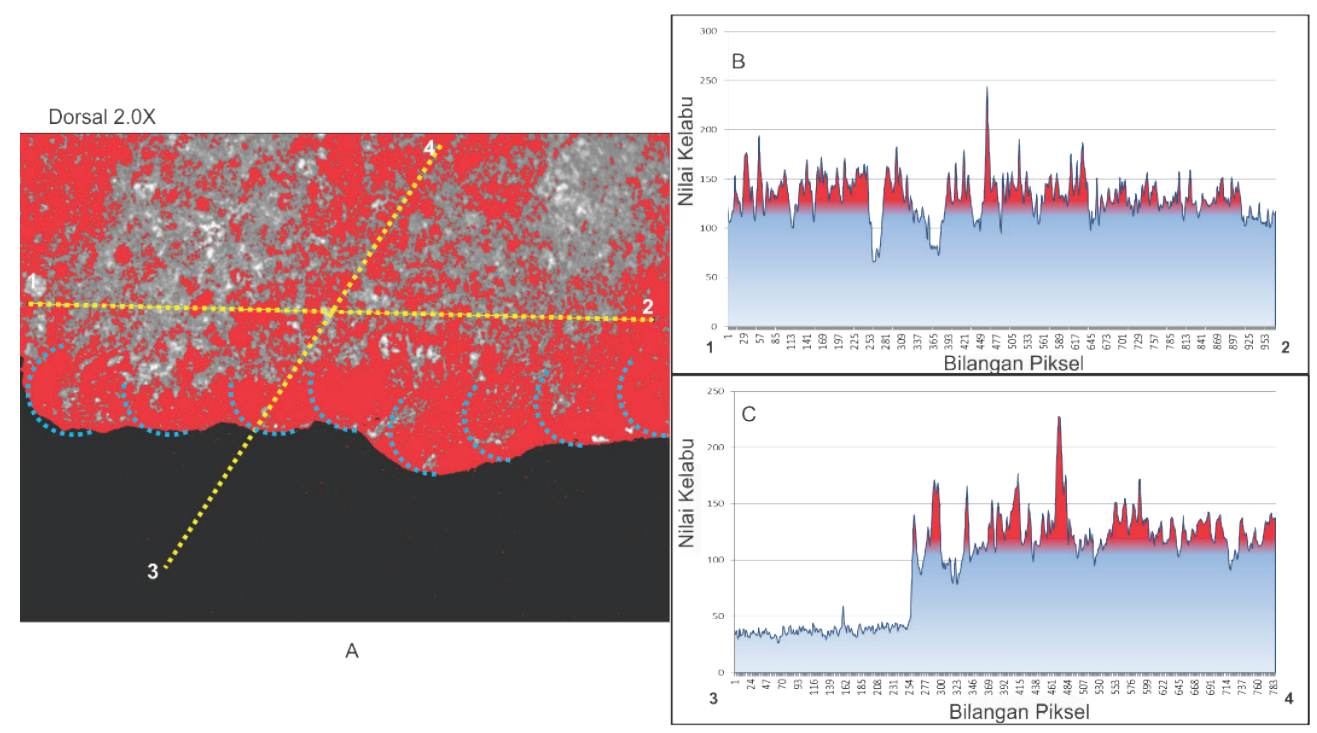

Rajah 8 (A) Analisis imej taburan kesan gilapan pada alat repih Madai dengan petunjuk berwarna merah yang mempunyai nilai kelabu yang tinggi bagi gerakan menegak. (B) Profil gilapan yang selari dengan mata tepi. (C) Profil gilapan menegak dengan mata tepi. 


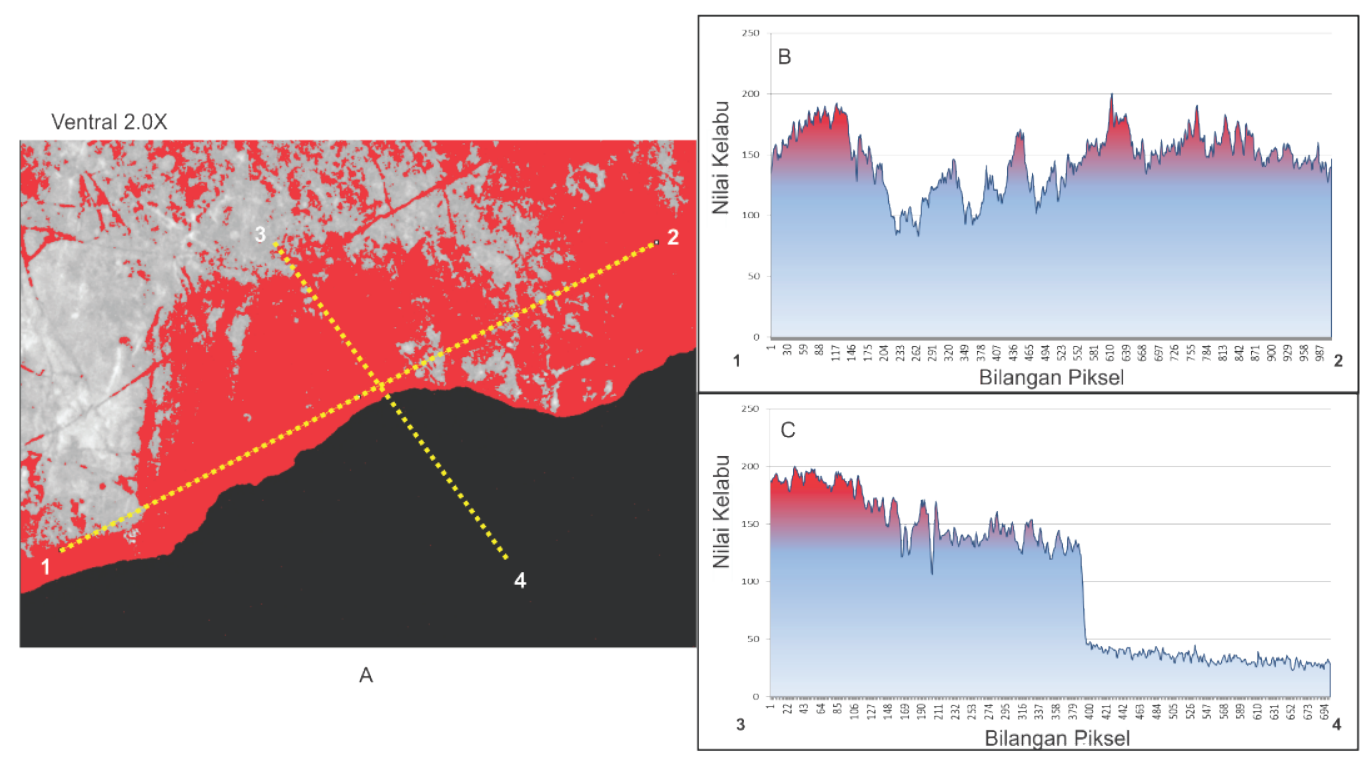

Rajah 9: A) Analisis imej taburan kesan gilapan pada alat repih Tingkayu dengan petunjuk berwarna merah yang mempunyai nilai kelabu yang tinggi bagi gerakan menegak. B) Profil gilapan yang selari dengan mata tepi. C) Profil gilapan menegak dengan mata tepi.

Tekstur permukaan mata tepi juga mempengaruhi taburan berwarna merah. Alat repih daripada Baturong dan Madai menghasilkan taburan merah yang bersela berbanding alat repih Tingkayu. Hal ini demikian kerana taburan gilapan yang tinggi menghasilkan nilai kelabu yang menyeluruh melalui analisis imej. Jenis taburan merah yang bersela ini adalah kerana saiz butiran batuan rijang tapak Madai dan Baturong berbeza dengan saiz butiran batuan Tingkayu. Perbezaan ini berlaku kerana saiz butiran batuan Tingkayu lebih halus berbanding dengan saiz butiran batuan Baturong dan Madai. Maka, sebaran taburan gilapan juga berbeza mengikut tekstur permukaan. Oleh sebab itu, perkembangan gilapan sukar untuk tergilap pada permukaan yang tidak halus dan tidak licin yang menyebabkan perkembangan nilai kelabu juga kelihatan bersela melalui analisis imej.

\section{Gerakan Putaran}

Hasil analisis imej menunjukkan gerakan putaran menghasilkan taburan merah secara bulatan pada hujung mata tirus alat repih bagi ketiga-tiga tapak (Rajah 10, Rajah 
11 dan Rajah 12). Hal ini menunjukkan ketiga-tiga alat repih ini digunakan untuk tujuan menggerudi atau menebuk lubang. Corak taburan bagi ketiga-tiga alat repih ini adalah sama, iaitu menghasilkan jenis taburan merah yang bersela dan terasing. Berkemungkinan ketiga-tiga alat repih ini digunakan untuk menebuk lubang pada media kerja yang lembut (kayu lembut atau cangkerang) atau alat ini tidak kerap digunakan, kerana kekerapan penggunaan alat repih juga mempengaruhi ketinggian konsentrasi sudut pada mata tepi (Andrefsky, 2004; Hiscock \& Allen, 2000; Odell, 2003). Cerapan penggunaan alat repih ini mempengaruhi perkembangan atribut taburan gilapan dan glos pada mata tepi.

Oleh itu, atribut kesan guna yang terhasil pada mata tepi alat repih juga dipengaruhi oleh kekerapan penggunaannya. Namun demikian, menurut Layton (1970), Ahler (1979), dan Bryan (1980) pula, sudut alat repih dipengaruhi oleh media kerja. Masyarakat awal telah menggunakan alat repih untuk pelbagai fungsi seperti memotong, meraut, mengikis, menghiris dan sebagainya. Maka, media kerja yang digunakan juga adalah berbeza, iaitu terdapat media kerja yang lembut, sederhana dan keras (Musil, 1988; Dockall 1997; Bamforth, 2010). Selain itu, menurut Fullagar dan Jones (2004), perkembangan atribut kesan guna ini bergantung pada jenis media kerja yang digunakan. Media kerja yang lembut seperti daging, kayu bertekstur lembut dan cangkerang yang tidak menghasilkan perkembangan atribut yang jelas. Sementara, media kerja yang keras pula menghasilkan atribut kesan guna yang lebih jelas. Maka, tahap kekerasan media kerja dan kekerapan alat repih digunakan mempengaruhi perkembangan gilapan pada mata hujung repihan. Hal ini secara tidak langsung menghasilkan taburan nilai kelabu yang bersela pada analisis imej.

Turut menjadi faktor yang mempengaruhi taburan berwarna merah yang bersela pada alat repih ini ialah tekstur permukaan batuan yang tidak licin dan tidak rata bagi alat repih tapak Baturong dan Madai. Permukaan batuan yang tidak rata menyukarkan berlakunya perkembangan gilapan pada mata hujung repihan. Oleh itu, perkembangan gilapan yang bersela terhasil pada mata hujung repihan. Maka, jenis taburan merah yang terhasil pada mata hujung repihan adalah terasing (Rajah 10 dan Rajah 11). Memandangkan batuan rijang daripada tapak Tingkayu lebih rata dan licin, maka perkembangan gilapan lebih mudah terhasil pada mata hujung alat repih. Namun begitu, alat repih daripada tapak Tingkayu juga menghasilkan taburan merah yang bersela disebabkan oleh cerapan penggunaan alat dan kekerasan media kerja yang digunakan. Jenis profil nilai kelabu yang terhasil bagi gerakan putaran pula adalah berbeza dengan gerakan melintang dan menegak kerana kecerunan nilai kelabunya bergantung pada mata hujung repihan (Rajah 10, Rajah 11 dan Rajah 12). 


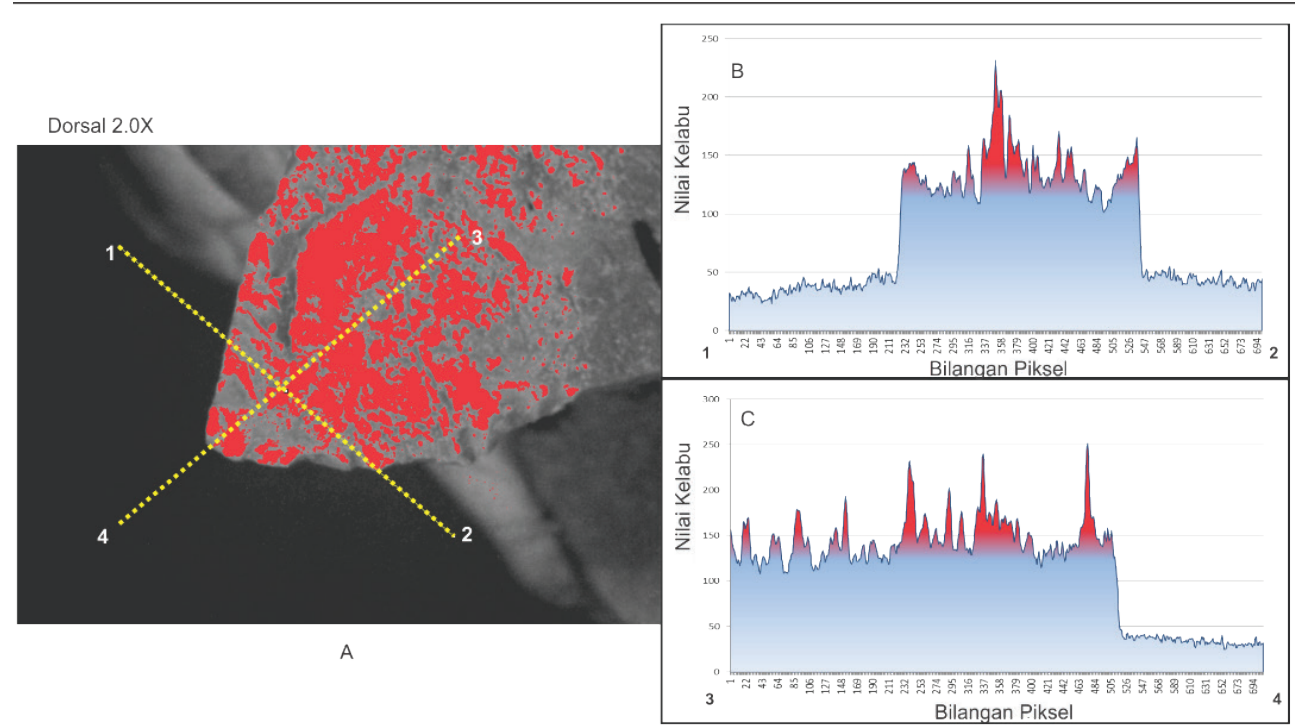

Rajah 10 (A) Analisis imej taburan kesan gilapan pada alat repih Baturong dengan petunjuk berwarna merah yang mempunyai nilai kelabu yang tinggi bagi gerakan putaran. (B) Profil gilapan yang selari dengan mata tepi. (C) Profil gilapan menegak dengan mata tepi.

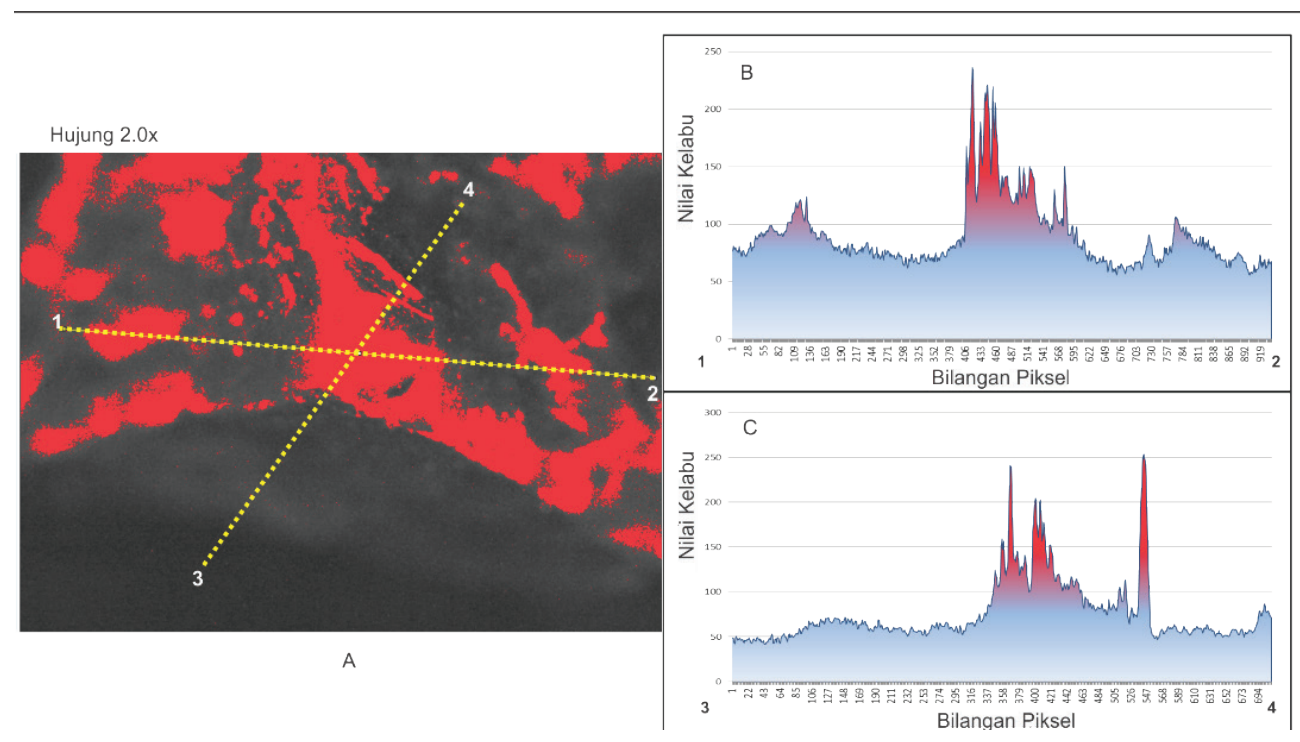

Rajah 11 (A) Analisis imej taburan kesan gilapan pada alat repih Madai dengan petunjuk berwarna merah yang mempunyai nilai kelabu yang tinggi bagi gerakan putaran. (B) Profil gilapan yang selari dengan mata tepi. (C) Profil gilapan menegak dengan mata tepi. 


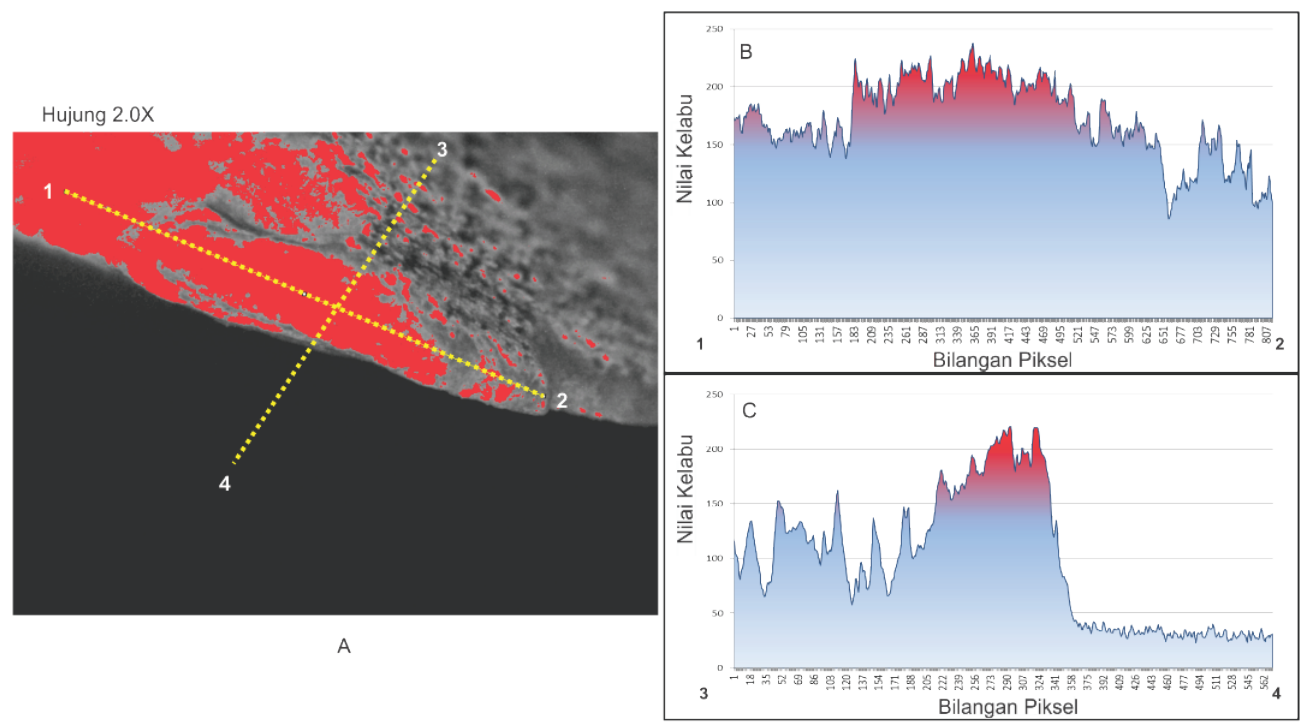

Rajah 12 (A) Analisis imej taburan kesan gilapan pada alat repih Tingkayu dengan petunjuk berwarna merah yang mempunyai nilai kelabu yang tinggi bagi gerakan putaran. (B) Profil gilapan yang selari dengan mata tepi. (C) Profil gilapan menegak dengan mata tepi.

\section{FUNGSI ALAT REPIH LEMBAH TINGKAYU}

Bagi tujuan mengenal pasti fungsi artifak alat repih ini, hasil analisis imej digunakan untuk mengenal pasti atribut perkembangan gilapan dan glos yang terhasil mengikut kepada aktiviti gerak kerja yang berbeza. Atribut ini digunakan sebagai perbandingan untuk mengenal pasti fungsi atau gerakan kerja pada alat repih. Gerak kerja yang telah dikenal pasti pada mata tepi alat repih bagi ketiga-tiga tapak ialah gerakan melintang, menegak dan putaran. Gerakan melintang terdiri daripada aktiviti menggergaji dan menghiris. Gerakan menegak melibatkan aktiviti meraut atau mengikis. Gerakan putaran pula, mewakili aktiviti menggerudi. Berkemungkinan, gerakan kerja yang berbeza akan menghasilkan atribut gilapan dan glos yang berbeza pada mata tepi alat repih yang telah digunakan. Maka hasil analisis imej tersebut mendapati alat repih di Lembah Tingkayu banyak digunakan untuk aktiviti pelbagai fungsi, iaitu sebanyak $44 \%$. Seterusnya aktiviti mengikis sebanyak $28 \%$, aktiviti meraut sebanyak $16 \%$, menggerudi sebanyak 6\% dan menghiris sebanyak 6\% (Rajah 13). 


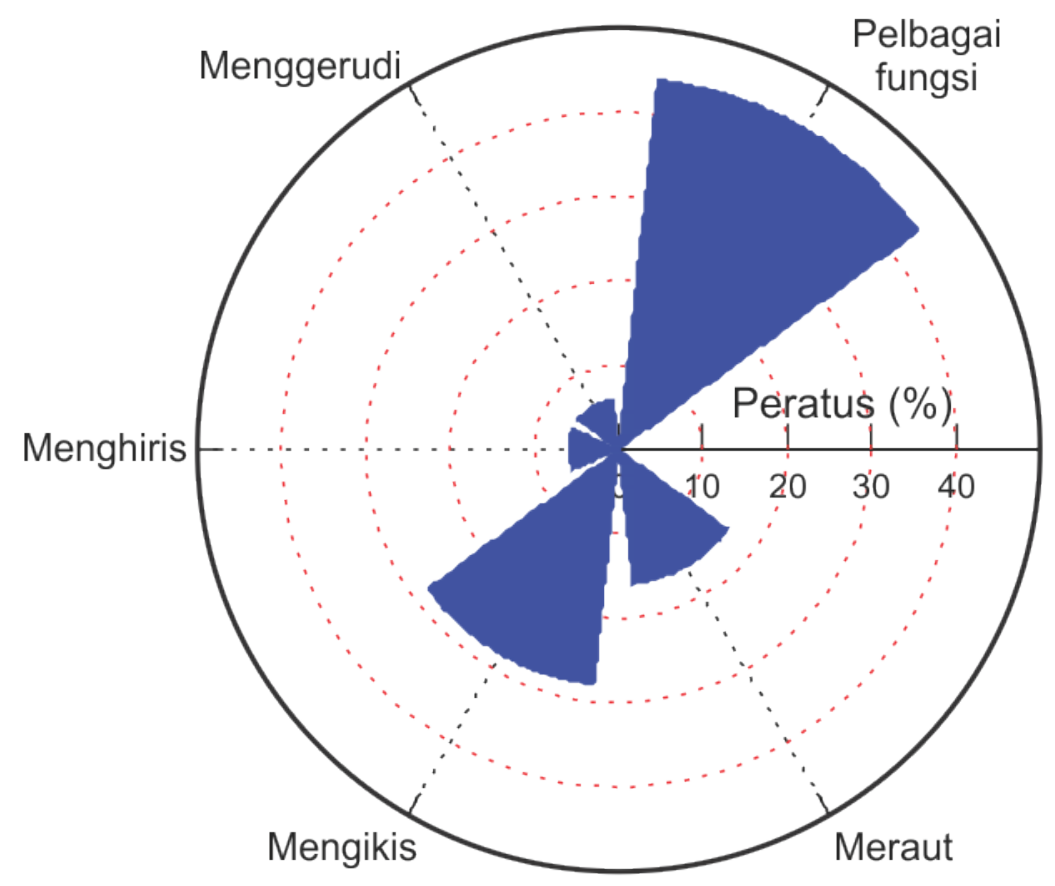

Rajah 13 Peratus keseluruhan fungsi alat repih di Lembah Tingkayu.

Alat repih bergerigi, didapati banyak digunakan untuk pelbagai fungsi bagi ketigatiga tapak, iaitu sebanyak 40\% bagi tapak Madai, sebanyak $46 \%$ bagi tapak Tingkayu dan tapak Baturong. Selain pelbagai fungsi, aktiviti mengikis juga didapati paling tinggi bagi tapak Tingakayu dan Baturong, iaitu sebanyak 36\% bagi kedua-dua tapak. Tapak Madai pula sebanyak 10\% bagi fungsi mengikis. Peratusan ini menunjukkan ketiga-tiga tapak mempunyai fungsi mengikis pada alat repihnya. Selain itu, terdapat fungsi meraut bagi ketiga-tiga tapak, iaitu sebanyak 10\% bagi tapak Madai dan 18\% bagi tapak Tingkayu dan Baturong. Berkemungkinan alat repih bergerigi banyak digunakan untuk aktiviti mengikis dan meraut, kerana menurut Dibble (1995) dan Lerner (2007a), alat repih mata tepi yang bergerigi banyak digunakan untuk mengikis kulit haiwan dan meraut buluh oleh masyarakat awal. Mata tepi bergerigi ini terhasil disebabkan oleh gerakan mengikis atau meraut yang menyebabkan mata tepinya terpecah yang menghasilkan mata tepi yang bergerigi (Tringham et al., 1974).

Hal ini demikian kerana alat repih bergerigi dikatakan terhasil daripada repihan batu teras atau repihan semasa membuat alat pebel yang digunakan secara terus tanpa 

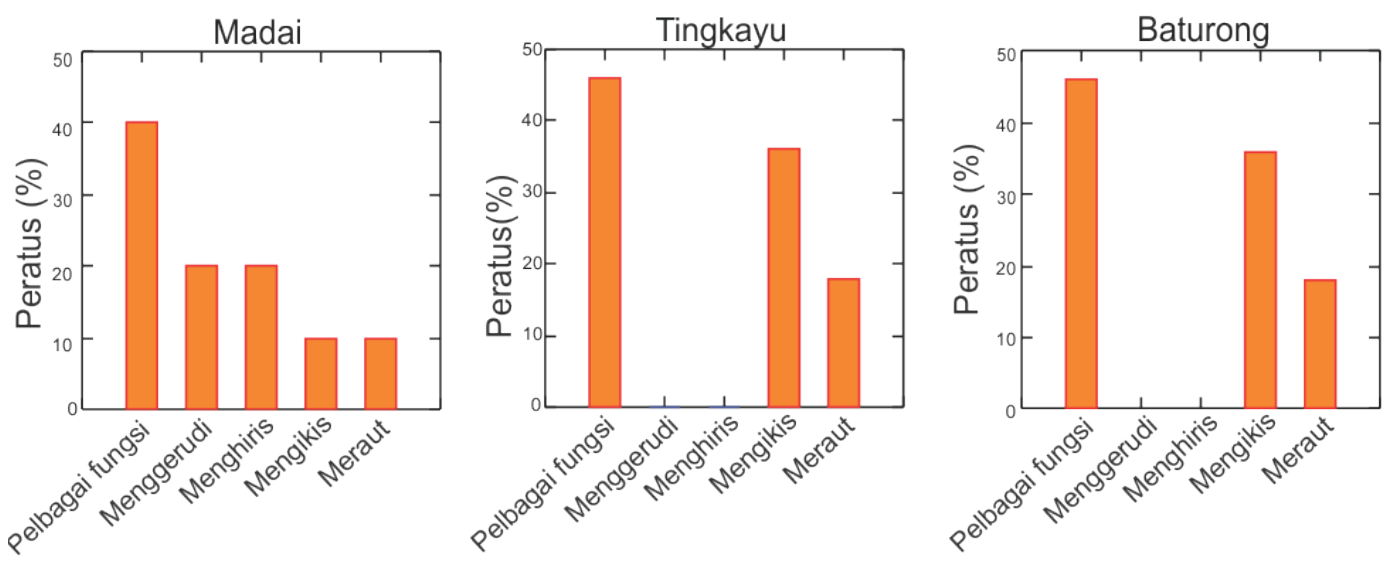

Rajah 14 Peratus fungsi bagi alat repih tapak Madai, Tingkayu dan Baturong.

perapian mata tepi (Evans \& Donahue, 2005; Martin, 2009). Kesan penggunaan pada mata tepi ini menghasilkan pecahan yang bergerigi pada mata tepi alat repih (Smith, 2006; Rabett, 2012). Sementara tapak Madai pula mempunyai fungsi menghiris $(20 \%)$ dan menggerudi (20\%) (Rajah 14). Hal ini membuktikan bahawa alat repih sesuai digunakan sebagai pisau bagi aktiviti menghiris (Andrefsky, 2008; Grace, 2012). Berdasarkan kajian etnografi oleh Beyin (2010) pula menunjukkan repihan bergerigi tirus digunakan untuk menebuk lubang pada siput atau cangkerang. Di tapak Tingkayu dan Baturong, alat repih yang ditemui tidak mempunyai fungsi menggerudi dan menghiris secara spesifik melainkan gabungan fungsi.

Didapati bahawa alat repih bergerigi Lembah Tingkayu banyak digunakan untuk pelbagai fungsi. Terdapat beberapa gabungan fungsi, iaitu fungsi mengikis dan menggergaji (29\%), fungsi mengikis dan menghiris (29\%), fungsi meraut dan menghiris (7\%), fungsi menggerudi dan menghiris (7\%), fungsi meraut dan mengikis (7\%), fungsi menggergaji dan mengikis (7\%), fungsi meraut dan menggerudi (7\%) dan fungsi gergaji dan meraut (14\%) (Rajah 15). Alat repih bergerigi lembah Tingkayu banyak digunakan di lokasi yang berbeza pada satu-satu alat repih. Berkemungkinan alat repih bergerigi yang dihasilkan mempunyai banyak mata tepi yang sesuai digunakan.

Selain itu, kemungkinan terdapat banyak lokasi dan gerakan ini adalah disebabkan masyarakat awal menggunakan mata tepi yang sama dengan fungsi yang berbeza sehingga mata tepi menjadi tumpul dan menggunakan sisi yang lain sebagai mata tepi 
yang baharu (Shott \& Weedman, 2007). Selain itu, banyak alat repih bergerigi yang dijumpai menghasilkan satu mata tepi dengan pelbagai fungsi. Hal ini menunjukkan alat repih di Lembah Tingkayu adalah lebih ekonomik kerana menggunakan satu alat repih untuk pelbagai fungsi.

Namun begitu, alat repih bergerigi ini dikenali sebagai alat yang tidak formal oleh Andrefsky (2005). Menurut Andrefsky (2004), alat batu jenis bifas, alat berperimping dan batu teras yang disediakan (prepared core) ialah alat yang dikatakan sebagai alat formal atau standard. Alat-alat ini dikatakan berguna untuk masyarakat yang nomadik disebabkannya boleh diubah suai dan mempunyai pelbagai fungsi. Alat yang tidak formal ialah alat repih jenis bergerigi (Andrefsky, 2005), iaitu alat yang digunakan secara langsung tanpa mengalami pengubahsuaian pada mata tepinya. Alat yang tidak formal ini menunjukkan bahawa masyarakatnya menghuni lebih lama di kawasan tersebut (Andresfsky, 2004). Walau bagaimanapun, menurut Manninen \& Knutsson

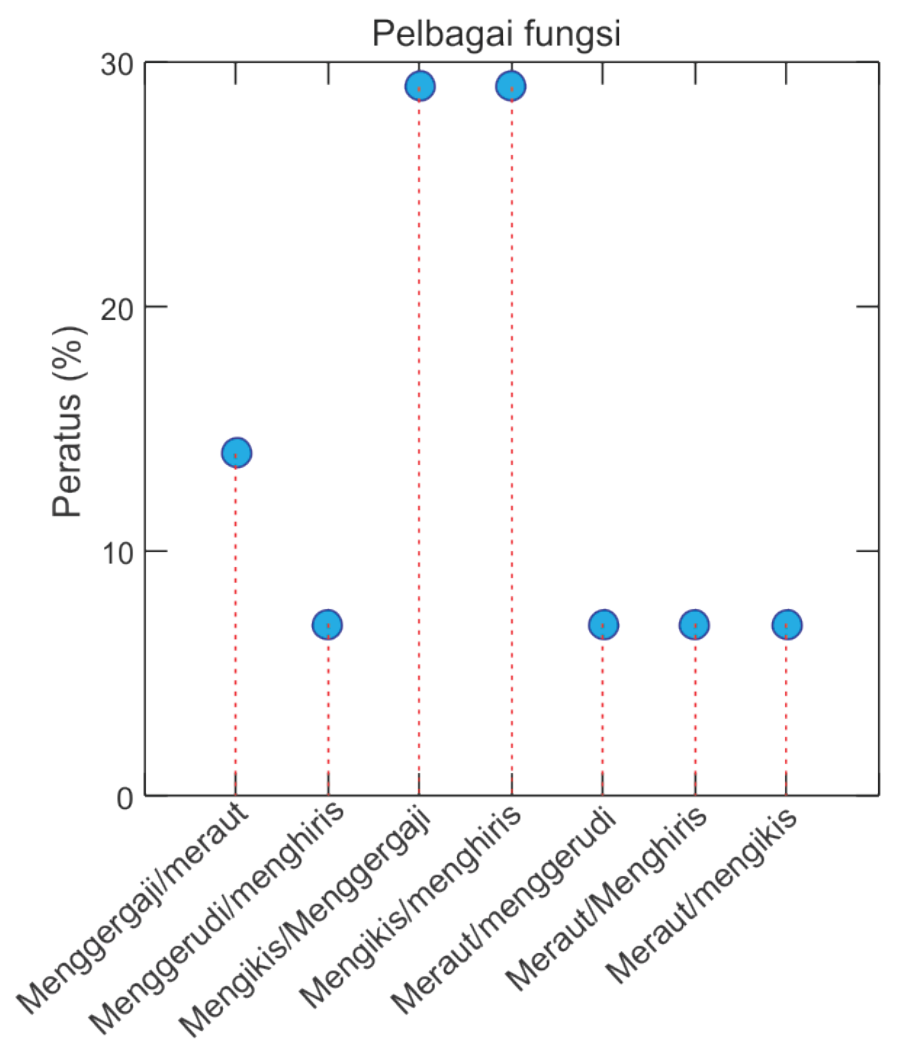

Rajah 15 Peratus keseluruhan bagi jenis alat repih pelbagai fungsi. 
(2014), penghasilan alat repih dan alat batu yang tidak formal adalah penting kepada masyarakat yang mempunyai mobiliti kediaman yang tinggi.

\section{KESIMPULAN}

Melalui analisis imej menunjukkan bahawa gerakan dan aktiviti yang berbeza menghasilkan atribut kesan guna yang berbeza terhadap mata tepi alat repihan. Hal ini berlaku sedemikian kerana gerakan melintang, menegak dan putaran menunjukkan perbezaan atribut kesan guna yang ketara terutama pada atribut perkembangan gilapan dan glos. Atribut perkembangan gilapan dan glos ini adalah paling penting dalam penentuan ketinggian nilai kelabu untuk dijadikan sebagai indikator bagi mengenal pasti fungsi pada alat repih Lembah Tingkayu. Perbezaan taburan merah jelas menunjukkan perbezaan bagi ketinggian gilapan dan glos untuk menunjukkan perbezaan tekstur permukaan batuan yang berbeza-beza bagi ketiga-tiga tapak. Tekstur permukaan mata tepi alat repih tapak Madai dan Baturong didapati tidak rata berbanding dengan permukaan mata tepi alat repih Tingkayu. Oleh itu, taburan merah yang dihasilkan pada permukaan mata tepi alat repih Baturong dan Madai adalah bersela berbanding dengan taburan merah yang terdapat pada permukaan mata tepi alat repih Tingkayu yang lebih bersifat berterusan dan sekata.

Hasil analisis imej menunjukkan bahawa masyarakat Lembah Tingkayu menggunakan alat repih untuk mengikis, meraut, menggerudi, menghiris, dan pelbagai fungsi. Hal ini membuktikan bahawa alat repih di Lembah Tingkayu digunakan untuk pelbagai fungsi dan tidak digunakan untuk menghasilkan alat sekunder seperti yang dikatakan oleh sebilangan pengkaji Barat. Selain itu, kajian ini adalah untuk menyokong kajian Bellwood (1988) yang menyatakan bahawa fungsi alat repih tapak Tingkayu berfungsi untuk menggergaji, meraut dan mengikis. Namun begitu, berdasarkan analisis imej menunjukkan bahawa tapak Tingkayu mempunyai alat repih dengan pelbagai fungsi. Analisis ini membuktikan bahawa masyarakat di Lembah Tingkayu tidak mementingkan bentuk alat repihnya, tetapi lebih kepada fungsi mata tepi alat repihnya. Oleh sebab itu, sifat alat repih yang amorfus di Asia Tenggara ini mungkin menunjukkan bahawa masyarakat Paleolitiknya mempunyai pengetahuan untuk menghasilkan alat repih yang pelbagai guna dan ekonomik. Hal ini dikatakan demikian kerana bentuk yang tertentu tidak diutamakan tetapi lebih kepada mata tepinya. 


\section{RUJUKAN}

Ahler, S.A., (1979). Functional analysis of Nonobsidian chipped stone artifacts: Terms, variables, and quantification. Dalam B. Hayden (ed.), Lithic use-wear analysis, Academic Press, Inc.

Anderson, P.C. (1980). A testimony of prehistoric tasks: Diagnostic residues on stone tool working edges. World Archaeology, 2(12), 181-194.

Andrefsky, W. (2004). Materials and contexts for a culture history of the Columbia Plateau. Dalam William Prentiss dan Ian Kuijt (ed.), Complex Hunter-Gatherers: evolution and Organization of Prehistoric Communities on the Plateau of North America, 23-35.

Andrefsky, W. (2005). Lithics: Macroscopic approaches to analysis. Cambridge University Press.

Andrefsky, W. (2008). Lithic technology: Measures of production, use and curation. Cambridge University Press.

Andrefsky, W. (2009). The analysis of stone tool procurement, production, and maintenance. Journal of Archaeological Research, 17, 65-103.

Bamforth, D. B. (2010). Conducting experimental research as a basis for microwear analysis. Dalam Jeffrey R. Ferguson (Ed.). Designing experimental research in archaeology. University Press of Colorado.

Barceló Álvarez, J. A., Pijoan-Lòpezm J., Toselli, A., \& Vila I Mitjà, Assumpció. (2008). Kinematics in use-wear traces: An attempt of characterization through image digitalization. Dalam Longo, L. dan Skakun, N. (Ed), 'Prehistoric Technology' 40 Years Later: Functional Studies and the Russian Legacy, British Archaeological Reports International Series Vol. 1783. Archaeopress.

Bar-Yosef, O., \& Wang, Y. (2012). Paleolithic archaeology in China. Annual Review of Anthropology, 41, 319-335.

Bellwood, P. (1988). Archeological research in South-Eastern Sabah. Sabah Museum Monograph, 2, 282.

Beyin, A. (2010). Use-wear analysis of obsidian artifacts from Later Stone Age shell midden sites on the Red Sea Coast of Eritrea, with experimental results. Journal of Archaeological Science, 37(7), 1543-1556.

Bryan, Alan L. (1980). The Stemmed Point Tradition: An Early Technological Tradition in Western North America. Dalam Swanson, H., Lucille, Jr., Harten, B., Claude, N., Warren, dan Donald, Tuohy, R., (Eds)., Anthropological papers in memory of earl. Idaho Museum of Natural History.

Cootes T. (2000), Model-based methods in analysis of biomedical images. Dalam Baldock, R. \& Graham, J., (Eds.). Image processing and analysis: A practical approach. Oxford University Press. 
Dennell, Robin W. (2009). The Palaeolithic settlement of Asia. Cambridge University Press.

Dibble, H. L. (1995). Middle Paleolithic scraper reduction: Background, clarification, and review of the evidence to date. Journal of Archaeological Method and Theory, 2(4), 299-368.

Dibble, H. L. \& Pelcin, A. (1995). The effect of hammer mass and velocity on flake mass. Journal of Archaeological Science, 22, 429-439.

Dockall, J. E. (1997). Technological and functional variability of convergent tools from Nahr Ibrahim, Lebanon: Behavioral implications for Levantine Mousterian technological organization. Tesis Doktor Falsafah, Universiti Texas (tidak diterbitkan).

Elton, S. (2008). The environmental context of human evolutionary history in Eurasia and Africa. Journal of Anatomy, 212(4), 377-393.

Evans, A. A., \& Donahue, R. E. (2005). The elemental chemistry of lithic microwear: An experiment. Journal of Archaeological Science, 32(12), 1733-1740.

Fullagar, R., \& Jones, R., (2004). Usewear and residue analysis of stone artefacts from the Enclosed Chamber, Rocky Cape, Tasmania. Archaeology in Oceania 39, 79-93.

Gao, X., (2013). Paleolithic cultures in China: Uniqueness and divergence. Current Anthropology, 54, 358-370.

González-Urquijo, J. E., \& Ibáñez-Estévez, J. J. (2003). The quantification of use-wear polish using image analysis. First results. Journal of Archaeological Science, 30(4), 481-489.

Grace, R. (1989). Interpreting the function of stone tools: The quantification and computerisation of microwear analysis. British Archaeological Reports International.

Grace, R.(2012). Interpreting the function of stone tools. Ikarus Books.

Graham J. (2000), Pattern recognition: Classification of chromosomes. Dalam Baldock, R. \& Graham, J., (Eds.) Image Processing and Analysis: a Practical Approach. Oxford University Press.

Gramfort, A., Poupon, C., dan Descoteaux, M. (2014), Denoising and Fast Diffusion Imaging with Physically Constrained Sparse Dictionary Learning. Medical Image Analysis, 18(1): 36-39

Harrisson, T. \& Harrisson, B. (1971) The Prehistory of Sabah. Kota Kinabalu (Sabah): Sabah Society, volume 4.

Hazarika, M. (2012). Lithic industries with Palaeolithic elements in Northeast India. Quaternary International, 269, 48-58.

Hiscock, P, Allen H. (2000). Assemblage variability in the Willandra lakes. Archaeology in Oceania, 35, 97-103.

Ibáñez, J.J., González-Urquijo, J.E., \& Gibaja, J., (2014). Discriminating wild vs domestic cereal harvesting micropolish through laser confocal microscopy. Journal of Archaeological. Science, 48, 96-103. 
Inizan, M.L., Roche, H., \& Tixier, J. (1992). Technology of knapped stone. Meudon Codex.

Jaffrie Ignatius (2000). Pulau Balambangan dan sumbangannya kepada zaman Paleolitik di Asia Tenggara. Tesis Sarjana (tidak diterbitkan). Universiti Sains Malaysia: Pulau Pinang.

Keeley, L.H. (1980) Experimental determination of stone tool uses. University of Chicago Press.

Layton, Thomas N. (1970) High Rock Archaeology: An Interpretation of the Prehistory of the Northwestern Great Basin. Ph.D. Dissertation (unpublished). Cambridge University.

Lerner, H. (2007a), Digital image analysis and usewear accrual as a function of raw material: An example from Northwestern New Mexico. Lithic Technology, 32,(1), 5167.

Lerner, H. (2007b), Lithic raw material variability and the reduction of shortterm use implements: An example from Northwestern New Mexico, British Archaeological Reports. Oxford.

Lerner, H. (2009) Lithic Raw Material Variability and Usewear Accrual on Shortterm Use Implements: An Example from Northwestern New Mexico. Dalam Sternke, F., Costa, L. J., \& Eigeland, L., (Eds.). Nonflint raw material use in prehistory: Old prejudices and new directions, Proceedings of the 15th Congress of the U.I.S.P.P. Archaeopress, Oxford: 8191.

Lerner, H., Dytchkowskyj, D., \& Nielsen, C. (2010). Raw material variability, use-wear accrual rates and addressing the ambiguity of some use-wear traces: An example from northwestern New Mexico. Riv Sci Preist LX, 309-329.

Manninen, M. A., \& Knutsson, K. (2014). Lithic raw material diversification as an adaptive strategy-Technology, mobility, and site structure in Late Mesolithic northernmost Europe. Journal of Anthropological Archaeology, 33, 84-98.

Mokhtar Saidin. (2014). Urutan Kronologi Prasejarah Sabah. Dalam Mokhtar Saidin \& Jeffrey Abdullah (Eds.). Sumbangan Sabah kepada Arkeologi Asia Tenggara: Hasil penyelidikan 20 Tahun (1993-2013). Monograf Muzium Sabah Volume 12. Jabatan Muzium Sabah.

Mokhtar Saidin. (1998). Kebudayaan Paleolitik di Malaysia - Sumbangan Tapak Lawin, Perak dan Tingkayu, Sabah. Tesis Doktor Falsafah (tidak diterbitkan). Universiti Sains Malaysia.

Martin, C. M. (2009). Analysis of flaked stone lithics from Virgin Anasazi sites near Mt. Trumbull, Arizona Strip (Unpublished Doctoral dissertation). University Of Nevada, Las Vegas).

Mellars, Paul. (2006). Going east: New genetic and archaeological perspectives on the modern human colonization of Eurasia. Science, 313, 796-800. 
Mijares, Armand (2002) The Minori Cave expedient lithic technology. Quezon City: Contributions to Archaeology Series. University of the Philippines Press.

Mokhtar Saidin dan Jeffrey Abdullah. (2007). Sungai Perak kuno: Sumbangannya kepada zaman Paleolitik di Malaysia. Jurnal Arkeologi Malaysia, 20, 14-21

Moreaud, M., Revel, R., Jeulin, D., \& Morard, V. (2009), Size of Boehmite Nanoparticles by TEM Images Analysis. Image Analysis and Stereology, 28, 187-193.

Musil, Robert R. (1988). Functional Efficiency and Technological Change: A Hafting Tradition Model for Prehistoric North America. Dalam Judith A. Willig, C. Melvin Aikens, \& John L. Fagan, (Eds.). Early cOccupation in Far Western North America: The Clovis-Archaic Interface, Nevada State Museum Anthropological Papers 21, Carson City: $373-388$.

Narr, Karl. (1966). Die frühe und mittlere Altsteinzeit Süd- und Ostasiens. Handbuch f ür Urgeschichte.

Odell, G. H. (2003) Lithic analysis. Manuals in Archaeological method, theory, and technique. Springer.

Otte, M. (2010). Before Levallois. Quaternary International, 223, 273-280.

Parr, G. \& W. Polzleitner (2001), Fundamentals. Dalam Kropatsch, W. G. \& Horst Bischof, Digital Iimage analysis: Selected techniques and applications, Springer.

Pawlik, A. (2004). The Palaeolithic site of Arubo 1 in central Luzon, Philippines. IndoPacific Prehistory Association Bulletin, 24, 3-12.

Pope, G.G., (1989). Bamboo and human evolution. Natural History, 10, 49-56

Rabett, R. J. (2012). Human adaptation in the Asian Palaeolithic: Hominin dispersal and behaviour during the late Quaternary. Cambridge University Press.

Rottensteiner, F. (2001). Precise photogrammetric measurement. Dalam Walter G. Kropatsch and Horst Bischof, Digital Image Analysis: Selected Techniques and Applications, Springer, New York,: 411-438.

Semenov, S. (1964). Prehistoric technology, diterjemah oleh M.W. Thompson, Cory, Adams \& Mackay, London.

Shott, M. J., \& Weedman, K. J. (2007). Measuring reduction in stone tools: an ethnoarchaeological study of Gamo hidescrapers from Ethiopia. Journal of Archaeological Science, 34(7), 1016-1035.

Smith, A. M. (2006). Characterizing Late Pleistocene and Holocene stone artefact assemblages from Puritjarra rock shelter: a long sequence from the Australian desert. Records of the Australian Museum, 58, 371-410.

Solheim, Wilhelm G., II. (1970). Prehistoric archaeology in eastern mainland Southeast Asia and the Philippines. Asian Perspectives, 13, 47-58.

Stemp,W.J., \& Stemp, M., (2001). UBM laser profilometry and lithic use-wear analysis: Avariable length scale investigation of surface topography. Journal of Archaeological Sciences, . 28, 81-88. 
Sussman C. (1985). Microwear on quartz: Fact or fiction? World Archaeol, 17, 101-111.

Tringham R., G. Cooper, G. Odell, B. Voytek, \& A. Whitman. (1974). Experimentation in the formation of edge damage: A new approach to lithic analysis. Journal of Field Archaeology, 171-196

Whittaker, J. C. (2010). Flintknapping: Making and understanding stone tools. University of Texas Press.

Xu, J., Janowczyk, A., Chandran, S., \& Madabhushi, A. (2011), A High-Throughput active contour scheme for segmentation of histopathological imagery. Medical Image Analysis, 15(6).

Yoo, T. S., \& Metaxas, D. N. (2005). Open science - Combining open data and open source software: Medical image analysis with the insight toolkit. Medical Image Analysis, 9(6). 